\title{
Em busca da terra sem males: violência, migração e resistência em Kaká Werá Jecupé e Eliane Potiguara
}

\author{
In search of a land without evil: violence, migration and resistance \\ in Kaká Werá Jecupé and Eliane Potiguara \\ En busca de la tierra sin males: violencia, migración y resistência \\ en Kaká Werá Jecupé y Eliane Potiguara \\ Leno Francisco Danner \\ Julie Dorrico* \\ Fernando Danner ${ }^{* *}$
}

\section{Resumo}

O artigo tematiza a literatura indígena brasileira produzida a partir da década de 1990, em especial nas obras de Kaká Werá Jecupé e de Eliane Potiguara, por meio da relação de violência histórica, migração forçada, ameaça de perda de identidade e luta política enquanto núcleo e mote dessa mesma literatura de autoria indígena. $\mathrm{O}$ argumento central a ser defendido está em que esses/as escritores/as são profundamente moldados/as e impactados/as pela violência simbólico-material a que foram submetidos/as em termos de nossa modernização conservadora, de modo que o medo da morte, a dor pela perda de seus territórios e pela negação de sua identidade cultural, a lembrança saudosista e melancólica da destruição de seu lar e dos seus, bem como a migração forçada, o não reconhecimento e a invisibilização sociais, a fome e a miséria vividas nas periferias da cidade, levam à construção de um relato autobiográfico, testemunhal e mnemônico da sua singularidade étnico-antropológica e da violência colonial que possui um sentido altamente político e politizante, profundamente carnal, pungente e vinculado. Desse modo, o que se pode concluir da leitura e do estudo da literatura indígena brasileira é exatamente esse sentido político que ela assume em termos de crítica social, resistência cultural, luta política e práxis pedagógica, uma literatura que sai da ficcionalidade e assume exatamente o papel de crítica, produzida pelas vítimas por si mesmas e desde si mesmas.

Palavras-chave: literatura indígena brasileira, violência, migração, resistência.

\section{Abstract}

This paper thematizes Brazilian indigenous literature produced since 1990s, looking specifically at the works of Kaká Werá Jecupé and Eliane Potiguara through the lens of historical violence, forced migration, loss of identity and the political struggle that is this literature's central theme. The main argument to be sustained is that

\section{Resumen}

El artículo tematiza la literatura indígena brasileña producida a partir de la década de 1990, en especial en las obras de Kaká Werá Jecupé y de Eliane Potiguara, por medio de la relación de violencia histórica, migración forzada, pérdida de identidad y lucha política como el núcleo y la motivación de esta misma literatura de autoría indígena. El argumento

\footnotetext{
* Doutor em filosofia e professor da Universidade Federal de Rondônia (UNIR), Porto Velho, RO, Brasil. (Dorcid.org/0000-00022332-3182 E-mail: leno_danner@yahoo.com.br

** Doutoranda em Teoria da Literatura na Pontifícia Universidade Católica do Rio Grande do Sul (PUC-RS), Porto Alegre, RS, Brasil. Dorcid.org/0000-0002-5428-2432 E-mail: juliedorrico@gmail.com

*** Doutor em Filosofia e professor da Universidade Federal de Rondônia (UNIR), Porto Velho, RO, Brasil. (D) orcid.org/0000-00024541-1204 E-mail: fernando.danner@gmail.com
} 
these writers are deeply shaped and impacted by symbolical-material violence to which they were subjected given our conservative modernization. As such, the fear of death, the pain felt over the loss of their territories and the negation of cultural identity, the nostalgic and melancholic memory of the destruction of their home and of their people, as well as the forced migration, the social misrecognition and invisibilization, the hunger and misery lived in the city peripheries, lead to the construction of an autobiographical, testimonial and mnemonic account of their ethnicalanthropological singularity and of colonial violence. Such violence is highly political and politicizing. Therefore, what can be concluded from reading and studying Brazilian indigenous literature is exactly this political sense undertaken by the literature itself through social criticism, cultural resistance, political struggle and pedagogical praxis, a literature that goes beyond fiction and assumes directly the role of critic, made by the victims from and for themselves.

Keywords: Brazilian indigenous literature, violence, migration, resistance. central a ser defendido está en que esos escritores/as son profundamente moldeados/as y impactados por la violencia simbólico-material a que fueron sometidos en términos de nuestra modernización conservadora, de modo que el miedo a la muerte, el dolor por la pérdida de sus territorios y por la negación de su identidad cultural, el recuerdo dramático y melancólico de la destrucción de su hogar y de los suyos, así como la migración forzada, el no reconocimiento y la invisibilización sociales, el hambre y la miseria vivida en las periferias de la ciudad, llevan a la construcción de un relato autobiográfico, testimonial y mnemónico de su singularidad étnicoantropológica y de la violencia colonial que posee un sentido altamente político y politizante, profundamente carnal, punzante y vinculado. De este modo, lo que se puede concluir de la lectura y del estudio de la literatura indígena brasileña es exactamente ese sentido político que asume en términos de crítica social, resistencia cultural, lucha política y praxis pedagógica, una literatura que sale de la ficcionalidad y asume exactamente la función de crítica, producida por las víctimas por sí mismas y desde sí mismas.

Palabras-clave: literatura indígena brasileña, violência, migración, resistencia.

O que eu acho é que muitas pessoas aqui estão incomodadas com que o mundo veja o Brasil na cara do Raoni. Porque o sinhozinho estava na sala tomando café, quando soube que alguém fugiu da senzala e foi fazer algazarra. Ficou apavorado, chamou o capataz e perguntou: "mas o que é isso? Fugiu um negro da senzala; foi fazer confusão aí no mundo". Quem pode mostrar a cara lá fora é o sinhozinho. Ele sai da sala com gravata e paletó e vai se exibir no paraíso. Agora, pessoal da senzala, das malocas, não pode sair por aí se exibindo de tanga, botoque e cocar. O incômodo é tão grande para uma parte da elite brasileira que é mais ou menos como se vocês estivessem exibindo um segredo de família para o público. O Brasil está vendendo o retrato do branco para o mundo há 500 anos. De repente, quando ele mostra o pessoal que não é branco...

Ailton Krenak

\section{Catarse literária e enfrentamento da violência simbólico-material}

Há uma correlação e uma dependência fundamentais entre o movimento indígena brasileiro e a literatura de autoria indígena produzida na esteira dele: a chaga da exclusão territorial, da descaracterização cultural, do silenciamento político e da violência simbólico-material que colocam a existência indígena em perigo servem como motes básicos para uma postura de vinculação pública, política e cultural dos povos, dos/as intelectuais e dos/as escritores/as indígenas. Se o movimento indígena brasileiro tem por meta enfrentar o processo de usurpação de seus territórios por meio da sua consolidação como sujeito político-cultural enraizado e atuante na esfera pública, de modo a superar a tutela tecnocrática, o paternalismo institucional e a responsabilidade relativa com que os indígenas tradicionalmente foram tratados pelo Estado brasileiro, os/as escritores/as indígenas buscam desconstruir os estereótipos e os preconceitos produzidos de modo extemporâneo e caricato pelo/a colonizador/a relativamente aos povos 
indígenas por meio da dinamização de uma voz-práxis autoral, em que os/as próprios/as indígenas falam diretamente à sociedade civil, contando-nos seja sua singularidade étnicoantropológica, seja os relatos de marginalização, de exclusão e de violência vividas e sofridas enquanto minorias político-culturais produzidas pela nossa colonização e, depois, em termos de modernização conservadora.

Esse pequeno e genérico introito, de todo modo, quer apontar para o núcleo fundamental do artigo, a saber, a análise da literatura indígena brasileira - nas figuras de Kaká Werá Jecupé e de Eliane Potiguara - enquanto uma voz-práxis autoral que constitui, dinamiza e impulsiona um eu-nós lírico-político que tem como núcleo de atuação uma perspectiva carnal, pungente, vinculada, política e politizante relativamente à condição e à causa indígenas no país. Essa vozpráxis estético-literária de caráter profundamente político transita da reafirmação cultural e da utilização da tradição étnico-antropológica à crítica do presente, ao enfrentamento da exclusão indígena no país, em todas as esferas da sociedade (inclusive a acadêmica). Ela é veículo de empoderamento e, em tudo isso, de expressão direta e autoral desses grupos na esfera pública e como sujeitos político-culturais. Ora, um das características mais marcantes da literatura indígena brasileira consiste exatamente no fato de que a violência simbólico-material caudatária da colonização e reproduzida na constituição e na evolução de nossa modernização conservadora impacta profundamente o imaginário, a autocompreensão normativa e as perspectivas desses/as escritores/as indígenas. Assim é que a expulsão de seus territórios físicos e culturais, o êxodo e o exílio permanentes e forçados impostos à bala, a deslegitimação normativa e o preconceito social imprimem a dor, a melancolia, o sentimento de perda e a possibilidade da morte física e simbólica enquanto constantes dessa mesma literatura indígena. Ela começa e se dinamiza na dor da espoliação, da violência gratuita, do descaso governamental, da fome e da miséria nas periferias do Brasil e, ao publicizar-se, traz à esfera pública todo o peso da colonização, desnaturalizando-a e politizando-a. Com isso, outro ponto fundamental dessa mesma literatura de autoria indígena, a ser desenvolvido pelo artigo, está em que tal situação de desterritorialização e de exclusão impulsiona uma perspectiva estéticoliterária ativista, militante e engajada por parte dos/as escritores/as indígenas, que reconhecem e afirmam exatamente essa politização que é inerente não apenas à sua produção estética, mas, antes disso, à sua condição como minorias político-culturais.

Antes de entrar propriamente no texto, gostaríamos de delimitar o sentido de dois conceitos que utilizamos ao longo do artigo para nos referirmos à literatura indígena brasileira. O primeiro deles é o conceito de voz-práxis, fala-práxis ou obra-práxis. Com ele queremos significar o fato de que a escrita das e pelas minorias possibilita uma perspectiva catártica e, portanto, reflexiva e reconstrutiva sobre si, sobre sua condição, sobre como se chegou a ser isso que se é enquanto minoria político-cultural violentada, como não lugar e ausência/recusa da voz (por parte da colonização, do colonizador). É uma voz que se torna ação reflexiva, uma ação reflexiva que se constitui e se dinamiza pela voz, no caso pela palavra escrita - uma voz-práxis, uma fala-práxis, uma obra-práxis, isto é, uma escrita que emancipa, que politiza, uma emancipação e uma politização que devêm da escrita, como escrita de si e por si mesmo/a. O segundo conceito é o de eu-nós lírico-político. Por meio dele, queremos exprimir uma condição fundamental da literatura de minorias de um modo geral e da literatura indígena brasileira em particular, a saber, o fato de que o/a escritor/a de minorias, na produção de sua obra-práxis, simplesmente não consegue separar (e nem o quer) história e pertença coletivas e história e consciência pessoais, no sentido de que, enquanto membro próprio a um grupo minoritário, ele/a reflete diretamente seja a singularidade que lhe constitui, seja o fato da violência simbólico-material que lhe produziu como grupo e, evidentemente, como indivíduo pertencente a esse grupo. Por isso, aliás, que a literatura de e pelas minorias é profundamente politizada e politizante, uma vez que: $i$ ) não se pode esconder o fato óbvio da diferença político-cultural; e, com isso, ii) não se pode contar de modo autobiográfico a própria história e a pertença étnico-grupal sem ao mesmo tempo politizar o contexto que produziu histórica e normativamente essas mesmas minorias. Em suma, com o conceito de eu-nós lírico-político queremos dar conta e expressar 
o profundo enraizamento do/a escritor/a de minorias para com o grupo de que faz parte e, assim, o quanto a história, a condição e o presente desse grupo lhe impactam a consciência, lhe definem as experiências e, com isso, determinam a produção de sua obra-práxis.

\section{É preciso politizar-se para existir!}

Queremos inserir a literatura indígena brasileira produzida a partir da década de 1990 para cá seguindo a proposição da professora Regina Dalcastagnè e a de Emilio del Valle Escalante, dentro do contexto maior da literatura de minorias (e produzida por estas minorias), como forma de, correlatamente: i) vincular-se em termos públicos, políticos e culturais, a partir de uma perspectiva de crítica social, de resistência cultural e de luta política do/a excluído/a por si mesmo/a e desde si mesmo/a; e, com isso, ii) construir relatos históricos, perspectivas artísticoculturais e sujeitos e conteúdos normativos que são alternativos às visões hegemônicas que servem de base à construção e à legitimação de nossa sociedade brasileira (Dalcastagnè, 2012, p. 17-24; Escalante, 2015, p. 1-2). Esta mesma sociedade brasileira, tanto na formulação de sua história quanto na promoção de suas matrizes culturais, evidentemente leva em conta as minorias de um modo geral e os povos indígenas em particular, mas, em grande medida, como sujeitos, temas e valores periféricos, que não fazem saltar, nessa perspectiva hegemônica própria às forças conservadoras que fundaram e que orientam a evolução de nossa sociedade, as contradições e os problemas agudos que nos constituem e nos dinamizam como sociedade brasileira (Fernandes, 2008, p. 338-361; Souza, 2012, p. 96-98). Ela apresenta-se, assim, como uma história pacificada, como um processo de integração e de identidade plenas, onde os conflitos no máximo causam arranhões, as contradições estão resolvidas e as consequências dos déficits de socialização e das lutas sociais não são graves. Em nossa história oficial, portanto, se trata de uma caminhada com um magnífico e sempre revivido final feliz para todos e por todos.

Ora, a invisibilização, o silenciamento e a despolitização dessas contradições e desses problemas acontece pari passu à - e na verdade por causa da - invisibilização, da exclusão, do silenciamento e, assim, da tentativa sempre permanente de despolitizar nossos sujeitos sociais não oficiais, em particular as minorias. Se as contradições fundantes da sociedade brasileira não levam à politização de nossas instituições, de seus sujeitos sociopolíticos basilares, dos valores e das práticas culturalmente vigentes, isso se deve, acreditamos nós, exatamente a essa prática de silenciamento, de invisibilização e de despolitização das minorias, empurradas no mais das vezes à esfera privada de vida que, por isso mesmo, enquanto esfera privada, não é vista, não é ouvida e nem sentida - uma prática de silenciamento, de invisibilização e de despolitização conduzida institucionalmente, diga-se de passagem. A história oficial de nossa sociedade, enquanto um processo de colonização e, depois, de modernização gradativos, a construção de uma sociedade nacional em que as diferenças - brancos/as, índios/as e negros/as - são integradas e promovidas de modo pacífico e harmônico, portanto, somente foi e talvez ainda seja possível de ser contada, reproduzida e legitimada com a recusa da voz e com a negação do ativismo a essas mesmas diferenças, tanto em termos institucionais quanto no que se refere à esfera público-política. Essas diferenças são produto do processo colonizatório e sua condição - como objetos do processo civilizacional e vítimas da violência histórica - representa um continuum no contexto de nossa modernização conservadora.

De fato, as diferenças são uma construção político-normativa em primeira mão, de modo que a política é sua condição, sua base e seu fim último, por assim dizer. Em que sentido as diferenças são uma construção político-normativa? Exatamente no fato de que esse status como alteridade, como quebra da identidade, da ordem e da estabilidade, não devém biológica ou religiosamente, não está dado, explícito na natureza e nem constitui uma imposição divina (de todo modo, a religião também é uma construção política, talvez até a biologia). Esse sentido negativo dado e justificado política e normativamente às diferenças, que não pode ser fundado em bases essencialistas e naturalizadas (as diferenças não são um dado $a$ priori, uma perspectiva desde sempre presente a nós, mas um fato $a$ posteriori, uma construção simbólica, um processo interativo), tem suas raízes na história e na vida sociopolítica próprias a uma dada sociedade e mais além, como é o caso da colonização europeia nas 
Américas, que é o nosso contexto teórico-político de fundo, neste texto. As diferenças são produzidas política e historicamente, e são produzidas por meio de um processo direto e pungente de violência simbólico-material em que o contato e o embate entre grupos sociopolíticos e/ou alteridades étnico-culturais levam ao etnocídio-genocídio e, gradativamente, à assimilação forçada, à inferiorização cultural, ao silenciamento político e à expulsão de seus territórios - culminando não poucas vezes na eliminação física e cultural. As minorias, aprendemos isso com a colonização europeia e com nossa modernização conservadora, são produto da violência simbólico-material e seu aparecimento da esfera pública, como sujeitos político-culturais, desvela, explicita, denuncia esse processo de violência simbólico-material.

As minorias explicitam a violência simbólico-material, não podem escondê-la (e nem querem fazê-lo). Repetimos: as minorias não podem esconder ou apagar a violência simbólico-material. Seus corpos, a cor de sua pele e de seu cabelo, o formato de seus lábios e narizes, a expressão linguísticoartística e a manifestação religioso-cultural, tudo isso, uma vez expresso e enraizado na esfera público-política, evidencia, reforça e atiça os processos, os sujeitos, as práticas e os valores próprios àquela violência simbólico-material produtora e reprodutora dessas mesmas minorias, dos processos de inclusão e de exclusão específicos à nossa sociedade, à nossa modernização conservadora. Seja naqueles indivíduos e grupos que se opõem publicamente a essa condição negativa em termos político-normativos, seja naqueles que se aclimatam a ela e a recriam afirmativamente (ou que assumem a desilusão de não serem reconhecidos pelas camadas e padrões hegemônicos, embora também se recusem a associar-se diretamente com esses grupos marginalizados - como era o dilema dos mulatos no Brasil Colônia), a condição político-normativa negativa das minorias e a história e o presente de sua condição não podem ser escondidos, não podem ser apagados. É justamente nesse sentido e a partir desse contexto que, conforme dissemos anteriormente, inserimos o protagonismo público, político e cultural das diferenças em termos de uma perspectiva de crítica social, de resistência cultural e de luta política, no Brasil hodierno. Seu gradativo aparecimento e consolidação na esfera pública, como sujeitos político-culturais ativistas, militantes e engajados desde sua condição, desnaturalizam e, assim, politizam a nossa vida social, nossas práticas institucionais, nossos valores e a história oficial do Brasil, porque essas mesmas minorias são o resultado da violência simbólico-material que esteve na gênese, no desenvolvimento e na evolução de nossa sociedade. Ora, essa é a base para compreendermos a literatura indígena brasileira produzida desde a década de 1990 em nossa sociedade.

Primeiramente, é preciso ressaltar que a literatura indígena brasileira surge e de desenvolve na esteira do movimento indígena brasileiro iniciado em meados dos anos 1970 como contraponto a isso que chamamos de paternalismo institucional e de tutela tecnocrática a que os povos indígenas estavam submetidos até então pelo governo militar, como resistência aos processos de desocupação territorial - vale dizer, de expulsão pura e simples de seus territórios tradicionais -, de descaracterização cultural e de exclusão política por parte do Estado brasileiro, naquele momento sob a orientação dos militares. No contexto dos anos 1970, em verdade, temos uma intensificação da atuação do Estado brasileiro com vistas à implantação de uma nova fronteira agrícola e de mineração nas regiões Centro-Oeste e Norte do país, o que levou exatamente ao confronto direto entre indígenas, militares e colonos vindos das regiões sul e sudeste, fato que ocasionou seja a expulsão de povos indígenas de seus territórios ancestrais, seja a sua descaracterização cultural (em virtude dessa perda dos territórios históricos, que, de todo modo, é uma constante desde nosso processo de colonização), seja, por fim, o crescimento da mortandade entre esses mesmos povos indígenas, tanto pela violência quanto pela fome e pelas doenças trazidas e impostas pelos colonizadores. Como ressalta Ailton Krenak, liderança indígena brasileira que esteve no núcleo de fundação do movimento indígena brasileiro, a razão de ser da criação e do protagonismo deste foi exatamente o enfrentamento de um processo de etnocídio/genocídio indígena institucionalizado, que se constitui na consequência direta desse processo de expulsão territorial, de descaracterização cultural e de alienação política gerado pelos programas de desenvolvimento do governo federal nas regiões Centro-Oeste e Norte do Brasil (mas também com incidências nas regiões Sul e Sudeste etc.). Ele nos diz, relativamente à constituição do movimento indígena brasileiro: 
As pessoas se perguntam o que tanta gente diferente que se encontrou naquele momento, índios de diversas etnias, ribeirinhos, seringueiros, podiam ter em comum. O que tinham em comum era o medo do progresso! No nosso caso, muito mais do que isso, era o medo do branco. Mas não de um branco qualquer. Existe todo um esquema, um acúmulo de capital... O índio achou que não sobreviveria a isso. Eu já me perguntei se iríamos sobreviver a isso (Krenak, 2015, p. 220). ${ }^{1}$

Temos, aqui, por conseguinte, o protagonismo público-político indígena como a única alternativa possível contra esse etnocídio-genocídio intensificado a partir dos anos 1970. Os povos indígenas, com suas lideranças e intelectuais, perceberam que, nesse contexto, somente o ativismo, a militância e o engajamento na esfera pública, como movimento político-cultural organizado, possibilitaria uma resistência mínima a esse processo institucionalizado de colonização que era imposto verticalmente à sociedade brasileira de um modo geral e aos povos indígenas em particular. E qual o ponto de crítica e a bandeira de luta assumidos e dinamizados pela União das Nações Indígenas, base fundamental do movimento indígena brasileiro? Foi exatamente a defesa de uma perspectiva de autonomia e de protagonismo políticos dos e pelos povos indígenas, contra a noção de responsabilidade relativa até então atribuída aos/às indígenas que, recusando-lhes a cidadania política, uma vez que os/as compreendia como sujeitos e comunidades não civilizadas, enquadrava-os/as e orientava-os/as em termos de paternalismo institucional e de tutela tecnocrática. Os/as indígenas não eram sujeitos público-políticos para o Estado brasileiro, e isso agravava sua situação de exclusão e de marginalização, respaldando diretamente a tomada de seus territórios e sua expulsão para as periferias das cidades ou para reservas, confinados/as e afastados/as não apenas dessa participação política de que falamos, mas também da própria constituição da sociedade brasileira. Ora, insurgindo-se contra o paternalismo institucional e a tutela tecnocrática e recusando, por conseguinte, a responsabilidade relativa a eles atribuída em termos político-jurídicos, os povos indígenas, organizados em torno à União das Nações Indígenas, passaram a assumir-se como sujeito político-cultural enraizado e atuante na esfera pública, a partir de uma postura de crítica social aguda em torno à condição e à causa indígenas no país. Ailton Krenak nos diz, mais uma vez, em termos de crítica e de recusa da tutela tecnocrática e de seu fundamento, a responsabilidade relativa:

Acho que você conhece a história das potências que colonizaram outras regiões do mundo e que tratam os nativos como cidadãos de segunda ou terceira categoria. Se você observar, a Inglaterra e a França mantinham até recentemente colônias na África e na Ásia, onde os nativos tinham o status aproximado da mula ou do cavalo. Aqui, no Brasil, os índios continuam tendo um status parecido com o de animais silvestres. Nós somos objetos da atenção do Estado enquanto seres que precisam ser preservados como fauna. Também temos a atenção do Estado como pessoas e indivíduos que precisam ser vigiados para que não entrem num processo de contestação do poder do Estado, de contestação da ordem estabelecida e de questionamentos dos crimes que foram praticados contra o nosso povo. Nós somos a memória viva e um testemunho sempre muito explícito da história recente da ocupação dessa região do mundo (Krenak, 2015, p. 85-86, grifo nosso).

Como estamos argumentando ao longo deste artigo, é esse o ponto fundamental da consolidação das minorias como sujeitos político-culturais e de seu ativismo, de sua militância e de seu engajamento em termos de esfera pública. Elas são memória viva e testemunho pungente da violência simbólico-material que perpassa e dinamiza a constituição de nossa sociedade e, ao aparecerem e se enraizarem na esfera pública, politizam nossas contradições, desvelam as fraturas e os problemas apagados, silenciados e mesmo deslegitimados pela normalidade institucional e pela história oficial. Nesse sentido, o falar e o agir por si mesmas e desde si mesmas constituem-se no núcleo teórico-político da emergência, da consolidação e do protagonismo das minorias na esfera pública e, em verdade, sua condição de sobrevivência e de florescimento. Com efeito, essa é a grande percepção dos grupos indígenas brasileiros, de seus/as intelectuais e escritores/as, e foi ela que dinamizou a constituição da União das Nações

${ }^{1}$ Ver também: Guajajara (2018, p. 21-28); Tukano (2017, p. 14-27); e Baniwa (2006, p. 56-85). 
Indígenas brasileiras e todas as suas ramificações desde então, como núcleo do movimento indígena brasileiro de um modo geral. Esse ativismo político-cultural e esse enraizamento na esfera pública colocam-se, em suma, como a alternativa e a atitude fundamentais em termos de crítica, de resistência e de fortalecimento, de modo que as minorias na esfera pública e como sujeitos político-culturais trazem para o cerne da vida social e das práticas institucionais a questão dos processos de integração, dos valores e dos símbolos constituintes de nosso país, inclusive as políticas reparatórias e as perspectivas de desenvolvimento e de integração possíveis diante desse contexto de uma modernização conservadora que produz e legitima a exclusão de grandes contingentes sociais. Não por acaso, Ailton Krenak considera a emergência, a consolidação e o protagonismo público, político e cultural do movimento indígena brasileiro como a segunda descoberta do Brasil, e a mais importante para os povos indígenas, segundo ele:

Eu acho que teve uma descoberta do Brasil pelos brancos em 1500 e depois uma descoberta do Brasil pelos índios nas décadas de 1970 e 1980. A que está valendo é a última. Os índios descobriram que, apesar de eles serem simbolicamente os donos do Brasil, eles não têm lugar nenhum para viver nesse país. Terão de fazer esse lugar existir dia a dia. Não é uma conquista pronta e feita. Vão ter de fazer isso dia a dia, e fazer isso expressando sua visão de mundo, sua potência como seres humanos, sua pluralidade, sua vontade de ser e de viver (Krenak, 2015, p. 248). ${ }^{2}$

Note-se, aqui, essa percepção de que o ativismo, a militância e o engajamento dos e pelos povos indígenas na esfera pública foi a descoberta fundamental que transformou o papel desses mesmos povos indígenas na vida social, política e cultural do Brasil hodierno: sua percepção de que a luta em torno à sua condição e à sua causa, o enfrentamento dos processos de exclusão, de marginalização e de violência, bem como a própria promoção de sua singularidade étnica, cultural e antropológica, passariam pela autonomia política, pelo engajamento substantivo em termos democráticos. Por outras palavras, tratou-se do mais fundamental aprendizado de uma democracia: o de que a proteção da autonomia pessoal-privada e a proteção de sua singularidade étnico-antropológica passam exatamente pela, dependem fundamentalmente de sua cidadania política, do ativismo direto na esfera pública. Ora, e o que tem isso a ver com a emergência e o desenvolvimento da literatura de autoria indígena no Brasil? Sobre isso, dois pontos. Primeiro, a similitude entre o desafio assumido pelo movimento indígena e o desafio assumido pelos/as escritores/as indígenas é clara: tratava-se de falar e de agir por si mesmos, de conquistar e de utilizar sua autonomia estético-política. Segundo, ambos os momentos e movimentos históricos têm uma meta similar: se o movimento indígena objetivava superar o paternalismo estatal, a tutela tecnocrática e a responsabilidade relativa, os/as escritores/as indígenas buscavam publicizar a própria voz como representantes das comunidades indígenas no país, a partir de uma fala-práxis autoral que se equiparava ou se contrapunha a perspectivas institucionalistas, cientificistas e tecnicistas extemporâneas a esses/as mesmos/as indígenas. E, no caso da literatura indígena, a constituição de uma voz-práxis autoral escora-se exatamente no exemplo do movimento indígena brasileiro, de conquista e de afirmação da cidadania política, da autonomia política, base para a emancipação e para a resistência - assim é que, inclusive, como veremos logo adiante, a literatura de autoria indígena assume-se como voz-práxis de caráter político-pedagógico e, com isso, alia-se diretamente com o movimento indígena brasileiro, promovendo-o.

A literatura indígena brasileira emerge e se desenvolve desde fins da década de 1980, consolidando-se a partir da década seguinte, tanto em termos da publicação, pelas próprias comunidades, de suas histórias de humanidade, possibilitadas pela educação escolar indígena de caráter bilíngue nas escolas indígenas, quanto pelo gradativo protagonismo de diversos/as escritores/as indígenas (Almeida e Queiroz, 2004, p. 195-201). Essa literatura de autoria indígena vem preencher uma lacuna existente em nossa sociedade e em nosso meio cultural: o fato de que, até então, os relatos sobre os povos indígenas teriam sido construídos por sujeitos extemporâneos, como escritores/as, antropólogos e cientistas sociais não indígenas. Assim é que podemos elencar dois momentos teórico-literários anteriores à literatura indígena, os quais esta vem enquadrar

2 Ver também: Munduruku (2012, p. 38-45). 
criticamente: o primeiro deles consiste no indianismo produzido por escritores do Romantismo brasileiro, como Gonçalves Dias e José de Alencar, em cujas obras os/as indígenas são o mote central, embora sejam representados de modo despersonalizado, posto que os pressupostos normativo-culturais que conduziam a abordagem desses autores tinham direta ligação com os autores e a cultura europeus - se tratava, portanto, de uma visão eurocêntrica, colonialista, caricata até, do/a indígena (veja-se o caso do "bom selvagem" de José de Alencar) (Sá, 2012, p. 27, p. 183203); o segundo deles, denominado de indigenista, próprio ao século XX com a consolidação das ciências sociais e, em particular, da antropologia, marcado pelo contato entre antropólogos e autoridades governamentais junto às comunidades indígenas, com o objetivo de estudar e de produzir conhecimento sobre os povos indígenas e fazer a mediação entre Estado e grupos antropológicos pré-modernos - mesmo aqui, a autoridade da interpretação sobre os povos indígenas cabia a tais antropólogos, com construção de conhecimento marcada pela centralidade da descrição técnica. Em um caso e em outro, os indígenas não figuravam como sujeitos, mas como objetos, conteúdo das abordagens - até suas histórias de humanidade seriam compiladas, em muitos casos, pelos antropólogos, que passavam a assumir autoria sobre elas. Ora, é a partir da constatação deste caráter periférico em termos teórico-normativos e dessa ausência de voz autoral dos/as e pelos/as indígenas que a postura dos/as escritores/as indígenas encontra substrato e é dinamizada. Conforme Kaká Werá Jecupé - que pode ser considerado como tendo publicado o primeiro livro de autoria indígena, em caráter individual, no Brasil hodierno, com sua obra Todas as vezes que dissemos adeus (1994) - nos diz relativamente ao surgimento do movimento pela literatura indígena nacional:

Naquela mesma época, em nossos encontros na aldeia guarani, eu conversava muito com o Daniel Munduruku. Ele já era um educador, formado em filosofia, e dava aula em escola pública. A gente conversava muito sobre como encontrar maneiras de potencializar esse trabalho de difusão. E tanto ele quanto eu gostávamos muito de literatura. Eu já estava ensaiando meus primeiros escritos literários. Então nós sonhamos, naquela época não era ainda criar um movimento de literatura indígena, mas em usar a escrita para falar de nossas culturas. Para falar diretamente. Para se ter uma ideia, até o início dos anos 1990, o que se tem notícia é de que praticamente tudo o que existe de escrito no Brasil sobre o índio, sobre os povos indígenas, sobre as culturas indígenas, não foi escrito por um índio. Foi sempre por um indigenista, por um antropólogo, por um sociólogo, por um estudioso, por um artista, por um poeta, por um escritor. Não que eu ache que isso seja uma coisa errada. Mas eu achava que, na medida em que nós nos tornássemos protagonistas de nossas próprias vozes, isso poderia gerar uma força muito grande, uma estratégia muito potente para se comunicar diretamente com a sociedade. E também para a sociedade ouvir diretamente a voz de um intelectual, de um cidadão, de um pensador, de um curador, de um contador de histórias vindo de um povo indígena (Werá, 2017, p. 25-26). ${ }^{3}$

Enfatizamos, da passagem acima, duas expressões fundamentais de Kaká Werá: a primeira, utilizar a escrita para falar de sua pertença, da condição e da causa indígenas; a segunda e consequente, a fala-práxis direta, sem mediações institucionalistas, cientificistas e tecnicistas - tal como a autonomia e o protagonismo político do movimento indígena brasileiro, aliás. Ora, essa fala-práxis direta, autoral, testemunhal, emanada por um/a indígena, no entender de nosso autor, permitiria um contato carnal e pungente, por parte da própria sociedade brasileira, com as testemunhas, com as vítimas de nosso processo de modernização conservadora. Aqui, o relato dos e sobre os povos indígenas seria construído e dinamizado pelos/as próprios/as indígenas, desde sua singularidade étnico-antropológica e a partir de suas experiências de marginalização, de exclusão e de violência próprias à sua situação como minorias naquele duplo significado que estabelecemos anteriormente. Por isso mesmo, Kaká Werá afirma que a literatura indígena tem um significado profundamente político; ela tem, inclusive, uma intenção política, que é exatamente o narrar autoral seja dessa singularidade étnico-antropológica, seja dessa condição de marginalização, de exclusão e de violência vividas e sofridas pelos povos indígenas. De modo consentâneo à autonomia política assumida e efetivada pelo movimento indígena brasileiro, a literatura de autoria indígena intenciona servir como ferramenta política de afirmação e de

\footnotetext{
${ }^{3}$ Ver também: Munduruku (2016, p. 190-193).
} 
efetivação da cidadania política indígena - a cidadania política como condição tanto da autonomia política quanto da autoria estético-literária, eminentemente imbricadas:

Para nós, a literatura indígena é uma maneira de usar a arte, a caneta, como uma estratégia de luta política. É uma ferramenta de luta. E por que uma luta política? Porque, à medida que a gente chega na sociedade e a sociedade nos reconhece como fazedores de cultura, como portadores de saberes ancestrais e intelectuais, ela vai reconhecendo também que existe uma cidadania indígena (Werá, 2017, p. 27). ${ }^{4}$

A voz-práxis estético-literária, dada sua estrutura aberta e antissistemática, dado seu caráter antiinstitucionalista, anticientificista e antitecnicista, viabiliza e potencializa a autoria indígena, permitindo o trânsito da oralidade para a escrita e desta para aquela, o que promove a autoexpressão da diferença desde sua singularidade, bem como a narração informal, mas por isso mesmo pungente, carnal e vinculada, das experiências de marginalização, de exclusão e de violência vividas e testemunhadas pelo eu-nós lírico-político. Enfatize-se que esta é outra característica fundamental da literatura de minorias de um modo geral e da literatura indígena brasileira em particular, a saber: a constituição de um eu-nós lírico-político que não dissocia pertença comunitáriagrupal e identidade pessoal, uma imbricação que correlaciona história coletiva e história pessoal, que vincula a condição e a causa do grupo ao protagonismo e à expressão dos/as e pelos/as escritores/as de minorias. Isso constitui uma voz-práxis ativista, militante e engajada, de expressão carnal, pungente e enraizada ao grupo ou à comunidade de que eles/as fazem parte. Aqui, a vozpráxis estético-literária possui um sentido político e politizante, uma vez que o relato do/a narrador/a, de caráter testemunhal e mnemônico, é sempre direto, experienciado em toda a sua crueza; e, por isso mesmo, a condição e a causa do grupo de que ele/a faz parte determinam e dinamizam a própria constituição e o próprio sentido da voz-práxis estético-literária, que é exatamente a politização de que falamos antes. Essa voz-práxis estético-literária, por conseguinte, como enfatizou Kaká Werá, objetiva a consolidação, a conquista da cidadania política dos/as e pelos/as indígenas, por causa dessa sua postura autoral e, por isso, nós qualificamos o eu-nós de lírico-político, como imbricação de arte e política, arte como política, política como arte. Na próxima seção, procuraremos exemplificar, a partir da produção literária de Kaká Werá Jecupé e de Eliane Potiguara, essa dinâmica da literatura indígena brasileira, isto é, a constituição de um eu-nós líricopolítico que vai da tradição ancestral à crítica do presente, que afirma a singularidade étnicoantropológica e publiciza o relato da situação de marginalização, de exclusão e de violência vividas e sofridas. Aqui, o drama do etnocídio/genocídio, a usurpação territorial e a violência simbólicomaterial se constituem na base teórico-política, no contexto vital e no mote a partir do qual sua produção literária tem sentido e se dinamiza.

\section{A voz-práxis estético-literária indígena como crítica}

Como dissemos, a violência histórica, a usurpação territorial e a condição como párias e sujeitos periféricos do processo civilizacional brasileiro determinam ab initio a compreensão de si e de seu lugar (ou o sentimento de falta dele) no mundo e, por conseguinte, a própria dinâmica da obra-práxis de Kaká Werá Jecupé e de Eliane Potiguara. Ele, um txucarramãe, e ela, uma potiguara, constroem uma expressão estético-literária que parte exatamente desse relato testemunhal, mnemônico e experiencial da perda do território, da negação cultural e do abandono e do isolamento sociais, levando-os, a partir disso, ao engajamento aberto em prol da condição e da causa indígenas no país, para o qual utilizam a literatura como instrumento político-pedagógico fundamental, como procuramos enfatizar na primeira parte desse texto. A memória da violência simbólico-material, da morte que lhes ameaça permanentemente a existência e de tudo o que lhes foi tirado e/ou negado, por conseguinte, está na raiz da autocompreensão e do protagonismo indígenas - lembremos novamente da fala-práxis de Ailton Krenak, que justificou a fundação e a vinculação público-política do movimento indígena brasileiro ao medo da destruição simbólico-material cometida por parte dos colonizadores,

${ }^{4}$ Ver também: Munduruku (2016, p. 172-178); e Krenak (2017, p. 72-78). 
situação que pouco mudou ontem e hoje. Não por acaso, as obras de Kaká e de Eliane começam exatamente sob o signo da violência, da destruição de suas comunidades e da fuga contra a sanha assassina do colonizador. Sobre isso, nos diz Kaká Werá Jecupé:

Quando eu era música entonada na barriga da mãe, nossa aldeia foi atacada. Homens empunhados de pequenos trovões de aço fizeram uma grande tempestade; lançando-se contra nós de todos os lados, fazendo chuva de chamas. Curumin, Cunhã, Tijari, Tieti, Mitã, Menononure, Aymeri, Tujá, Tujá-I; corpos destes nomes ao chão, como um estio fúnebre. Quando a última oca derramou sua última lágrima de fogo e se desfez em cinza, restaram pouco mais de oito parentes, entre eles a anciã Meire-Mekrangnotire e a filha Yakamara, que viria a ser a mãe que me semearia ao mundo (Jecupé, 2002, p. 22).

Veja-se também o poema "Fim de minha aldeia", de Eliane Potiguara:

Tenho medo das coisas que falo

Que mais parecem profecias

De tudo mais que falei

Hoje estou tão só, triste e descontente

Perdi o meu amor

Perdi minha razão

Dói-me profundo

Profundamente o coração.

Choro intranquila, sofro a desgraça.

Vivo o desamor na solidão

E por onde passo

Há só lembranças

De uma aldeia acabada.

Eu tenho medo das coisas que falo

Que mais parecem profecias

Pois de tudo, tudo que falei

Hoje estou sofrida, amargurada

Perdi minha essência

Grito traída, canto a trapaça

Sou a própria tristeza

Transformei-me numa constante ameaça.

Agora não rio, não sonho

Não suporto mais nada

Uma dor aguda me sufoca, me maltrata

É a dor da saudade que me mata (Potiguara, 2018, p. 33).

É possível perceber-se, primeiramente, nessas passagens, como uma característica marcante da literatura indígena brasileira, exatamente esse sentido autobiográfico do eu-nós lírico-político: ele vivenciou o que está narrando e, com isso, seu relato ultrapassa o aspecto meramente ficcional para assumir, como seu qualificativo central, um aspecto de verdade que em geral atribuímos ao juízo científico produzido dentro de um grupo de pesquisa, dentro de um gabinete, centralizado em uma instituição - a institucionalização como a base, o caminho e o qualificativo fundamentais para essa cientificidade, para essa objetividade do juízo. Aqui, entretanto, há uma diferenciação aguda entre isso que chamamos de juízo científico e este relato testemunhal dinamizado em termos literários, por parte das minorias: o juízo científico, de acordo com o paradigma normativo da modernidade, é construído e assume que sua legitimidade devém de um procedimentalismo imparcial, neutro, impessoal e formal, altamente institucionalizado e dependente da validação de uma comunidade de pesquisa que se utiliza basicamente de uma postura lógico-técnica, uma comunidade que é endógena e que trabalha na trama tradicional de esotérico (para si) e exotérico (para os/as leigos/as) (Habermas, 2012, p. 90-141); a voz-práxis estético-literária das minorias, em contrapartida, apresenta esse aspecto carnal e pungente de um eu-nós lírico-político que viveu, que testemunhou, que sentiu no corpo e na própria autocompreensão normativa a chaga da violência simbólico-material, sendo em grande medida produzido e derrubado por ela, bem como, certamente, motivado em sua luta. Trata-se, aqui, de um eu-nós lírico-político cuja única arma é exatamente a publicização de sua 
história de vida, de seu relato da própria marginalização. Aqui, ele não se separa dela, não há como assumir impessoalidade, imparcialidade e neutralidade diante da própria vida destruída, diante da própria dignidade negada. A única opção que lhe resta, em termos de crítica, de resistência e de luta, é a enunciação de sua condição, a fala-práxis em torno à sua diáspora, posto que ninguém pode fazer isso pela vítima, pela minoria, que é sempre insubstituível estética e politicamente falando. Por isso, não nos enganemos: a literatura de minorias de um modo geral e, em nosso caso, a literatura indígena brasileira em particular contêm um cunho de verdade que minimiza ou até erradica a ficcionalidade própria à literatura moderna (e até sua orientação individualista), constituindo-se, por isso mesmo, em conteúdo e em voz-práxis diretamente políticos e politizantes. É nesse sentido, aliás, que os/as escritores/as indígenas afirmam estar utilizando a literatura como uma perspectiva de crítica social, resistência cultural, luta política e prática pedagógica para si em primeiro lugar, para a sociedade envolvente em um momento posterior, ou seja, é em termos de relato vivido e sofrido, verdadeiro porque experienciado pela própria vítima que narra, que a literatura indígena pretende-se instrumento político e politizante (Jekupé, 2009, p. 5-38).

Note-se, em segundo lugar, como característica marcante da literatura de autoria indígena no Brasil, a centralidade da memória de quem se é e de como se chegou a ser isso que se é, de onde se saiu e para onde se está indo. A literatura indígena é profundamente perpassada e orientada pela memória de sua condição, de sua história, de modo que o passado vivido - e, nele, a violência é um dos aspectos mais marcantes - determina poderosamente a autocompreensão normativa que se tem no presente, e isso de modo totalmente pungente. Certamente não é uma memória apenas de dor, senão que contém em si a valorização e a afirmação da ancestralidade, o saudosismo da aldeia onde se vivia, da família e dos amigos com quem se estava, dos trabalhos e dos festejos que se fazia. Mas, em ambos os casos, trata-se de uma memória profundamente melancólica, para se dizer o mínimo, da vida destruída por meio da violência simbólico-material que se sofre como diferença - "tenho medo das coisas que falo", nos disse acima Eliane Potiguara, querendo explicitar exatamente essa ideia de que essas lembranças são sempre salgadas com as memórias do sangue derramado, do estupro sofrido e da dignidade negada. Com efeito, no mesmo diapasão, a obra-base de Kaká Werá Jecupé, Oré Awé Roiru'a Ma: todas as vezes que dissemos adeus, torna-se pungente exatamente por essa ênfase permanente, melancólica e triste, na lembrança de uma vida destruída, de uma fuga sempre forçada e, por fim, de uma voz que grita e, em muitas situações, recebe como resposta ou o descaso, ou o desprezo exatamente por não ser reconhecida como uma voz. Ele diz:

As imagens dançam na minha cabeça. Vejo minha pintura de rosto. Pintura de um povo antigo. Meu corpo dança no vento. Boca de jaguar me ataca os pés. Flechas correm sobre a aldeia. Tiros. Tiros. Tiros. Sons de trovão. Minha cabeça troveja lembranças. Vejo crianças cantando hinos brancos. Vejo uma aldeia se erguendo na beira de um rio. Vejo meu corpo vestido de uma remendada camisa amarela. Ouço rezas e vejo relâmpagos (Jecupé, 2002, p. 23). ${ }^{5}$

Tiros, tiros e mais tiros - eis o ponto fulcral, o drama vivido, a lembrança inapagável, que a literatura indígena publiciza de modo agudo. Isso poderia parecer "vitimismo", ou o popular "mimimi", ou até "forçação de barra", como estamos acostumados a ouvir com tanta frequência nestes tempos estranhos que vivemos. A isso responde Eliane Potiguara com uma afirmação ainda mais estarrecedora: "Eles criticam / Por nos encontrar nas estradas / Alegrem-se / Por não nos encontrar ainda nos hospícios!" (Potiguara, 2018, p. 37). Note-se, aqui, que essa situação dramática, retomada sempre e sempre pelo fato de que, como dissemos acima, um/a representante de minoria não pode esconder a violência simbólico-material que lhe foi imposta (porque, como minoria, ele/a já é violência simbólico-material em toda a sua crueza), incomoda e escancara as fraturas sociais pulsantes em nossa sociedade. A lembrança permanente da violência, o clamor da desigualdade e a potência da contradição causam desconforto tanto no âmbito das instituições e dos sujeitos institucionalizados quanto na esfera da sociedade civil, entre os diferentes e às vezes contrapostos estratos sociais, acostumados/as que estamos com a normalidade apolítica e com a imobilidade histórica, de uma vida que se processa e que passa de modo apolítico. Nesta como naquele o argumento do vitimismo, ou do mimimi, ou da forçação de barra é usado para emperrar o

${ }^{5}$ Ver também: Jecupé (1998, p. 13-26). 
pensamento crítico e a emancipação que devêm de um gesto simples, mas radical: olhar e ouvir as minorias, reconhecer e acessar as diferenças. Contra isso, isto é, contra a democracia que urge, que pulsa incessantamente e que incomoda, somente o não pensar, a surdez e a cegueira para com o/a outro/a, excluído/a e marginalizado/a, e em outros casos a eliminação física, são o núcleo duro da violência que sustenta e reproduz a injustiça, que naturaliza e idealiza o processo civilizacional e, assim, que tenta a todo custo despolitizar o presente pela negação do óbvio ululante: de que ele foi construído e tem uma história complexa que pode ser acessada quando se ouve, se vê e se fala com as diferenças. "Alegrem-se porque estamos nas estradas, e não nos hospícios!”, diz Eliane Potiguara, mas veja-se que a condição das minorias transita de uma área para outra, ora na estrada, ora no hospício, e provavelmente no cemitério.

Em terceiro lugar, podemos perceber na literatura indígena de Kaká Werá Jecupé e de Eliane Potiguara o lamento pelo mundo perdido, pela violência sofrida e pela identidade negada. É um brado de angústia e um questionamento pungente para si e diretamente para a sociedade envolvente sobre o destino dos párias do processo civilizacional, sobre o passado, o presente e o futuro que lhes envolve e que é representado pela dinâmica cultural e institucional própria à sociedade brasileira, profundamente afetada pelo colonialismo, pelo autoritarismo e pela segregação. É um questionamento que provoca, a partir do próprio lugar de fala e, com isso, com base nas experiências de marginalização e na condição como negatividade, como violência simbólico-material, a história da sociedade brasileira e o dia a dia de nossa esfera pública, em que a questão das minorias pouco aparece, em que a condição e a causa indígenas possuem, no mais das vezes, um lugar periférico. Qual será nosso futuro, questionam os povos indígenas, uma vez que nosso passado foi de etnocídio? Que estão fazendo e o que podemos fazer de nosso presente? Note-se que esse grito de lamento e essa postura de questionamento e de crítica motivam exatamente a publicização de si e de sua história, um enquadramento direto e pungente da sociedade envolvente, pelo fato de que, mais uma vez, é exatamente esse contato social, calcado agora na autonomia e no protagonismo político dos povos indígenas, de seus/as intelectuais e escritores/as, que dá a tônica de nossa esfera pública - se a colonização foi marcada pelo etnocídio e se nossa modernização conservadora confinou os povos indígenas em reservas ou os empurrou para os recônditos mais distantes de nossas matas (ou para a periferia de muitas cidades), o ativismo indígena na contemporaneidade, tanto em termos políticos quanto em termos estéticos, supera essa periferização e essa invisibilização por meio de um engajamento esclarecido e crítico, feito em nome dos/as próprios/as indígenas e por eles. Diz Eliane Potiguara, em seu enquadramento da sociedade brasileira:

Que faço com a minha cara de índia?

E meus cabelos

E minhas rugas

E minha história

E meus segredos?

Que faço com a minha cara de índia?

E meus espíritos

E minha força

E meu Tupã

E meus círculos?

Que faço com a minha cara de índia?

E meu Toré

E meu sagrado

E meus "cabocos"

E minha Terra?

Que faço com minha cara de índia?

E meu sangue 
E minha consciência

E minha luta

E nossos filhos?

Brasil, o que faço com a minha cara de índia?

Não sou violência

Ou estupro

Eu sou história

Eu sou cunhã

Barriga brasileira

Ventre sagrado

Povo brasileiro

Ventre que gerou

O povo brasileiro

Hoje está só...

A barriga da mãe fecunda

E os cânticos que outrora cantavam

Hoje são gritos que guerra

Contra o massacre imundo (Potiguara, 2018, p. 29-30).

Que faço com minha condição, com minha vida, Brasil? - pergunta-se Eliane Potiguara. Veja-se essa potência estético-política e essa perspectiva de empoderamento viabilizadas pela voz-práxis literária: aqui, se trata de uma expressão autoral do eu-nós lírico-político que atinge diretamente o núcleo civilizacional de nossa sociedade e, como enfatizamos ao longo do texto, desvela a violência, as fraturas e as contradições que dinamizam nossa evolução e definem muitos de nossos problemas e de nossas potencialidades hodiernos. Um desses problemas, que é também um de nossos grandes desafios, consiste exatamente na correta reavaliação de nossa história nacional, da efetiva maturação de nossa esfera público-política democrática, da valorização dessas minorias que, produzidas por meio da violência simbólico-material colonizatória, também permitem a assunção e o desenvolvimento de perspectivas críticas relativamente ao presente e ao futuro do Brasil, viabilizando, inclusive, pensar-se políticas reparatórias e educacionais que possam minimizar e talvez até erradicar o preconceito, a desigualdade e a exclusão delas e de grupos sociais vulneráveis (Jekupé, 2002, p. 13-36; Esbell, 2013, p. 25). A exclusão e a marginalização sociais, aliás, são, em nossa compreensão, um quarto motivo fundamental na construção e na dinamização da literatura de minorias de um modo geral e na literatura indígena brasileira em particular, especialmente, para nosso caso, nas obras de Kaká Werá Jecupé e Eliane Potiguara. Assim é que a pergunta que ambos se fazem, frequente e pungentemente, sobre seu lugar no mundo, da mesma forma como a angústia e a tristeza que sentem pelos constantes deslocamentos vivenciados, não é nada mais, mas também nada menos, que o resultado de não se ter lugar nenhum, seja ele simbólico, seja ele territorial. Por outras palavras, o sentimento de ser um exilado em seu próprio país, nesses/as autores/as, sem terra, sem cultura, sem direitos, com a vida sempre ameaçada, com a dignidade fortemente deslegitimada, tem sua razão de ser exatamente na expulsão territorial e na migração forçada às quais são empurrados os povos indígenas brasileiros, as comunidades próprias a ambos/as os/as escritores/as. Ora, essa situação de pária, de estrangeiro, de negatividade em seu próprio país impacta profundamente a personalidade de nossos/as indígenas, situação que se reflete nas próprias produções literárias por eles/as desenvolvidas:

No universo de gestos

Teus olhos são mensagens sem palavras

Tua boca ainda incandescente

Me queima o rosto na partida

E tuas mãos...

Ah! Não sei mais continuar esses cânticos

Porque a mim tudo foi roubado. 
Se ainda consigo escrever alguns deles

Só é fruto mesmo da mágoa que me toma a alma

Da saudade que me mata

Da tristeza que invade todo o meu universo interno

Apesar do sorriso na face... (Potiguara, 2018, p. 34).

Aldeias destruídas, familiares e amigos assassinados, perseguição permanente, situações que fazem parte da e que influenciam profundamente a constituição do espírito indígena determinando, no mais das vezes, a consolidação da miséria material e moral, a perda de identidade e a depressão-desilusão desses grupos indígenas. Apenas para se citar um exemplo, a expulsão de seus territórios, a perseguição constante e o preconceito sofrido levaram o pai de Kaká Werá Jecupé ao alcoolismo e à morte, situação similar que aconteceu à avó materna de Eliane Potiguara, que também se tornou alcóolatra. O fato, aqui, é que há uma correlação estreita, na consciência de si, na autocompreensão de si dos/as escritores/as e intelectuais indígenas, entre expulsão territorial, migração forçada e violência simbólico-material com perda de identidade e miséria moral e material. Como se pode perceber em seus relatos autorais, não há como compreender-se e afirmar-se como indígena, na sua singularidade e nos seus dramas, sem concomitantemente trazer-se à tona a memória das perdas, das sempre inúmeras e permanentes perdas (das sangrentas perdas!) que fazem parte da vida das minorias, da condição dos povos indígenas como periferia e párias do nosso processo civilizacional. "Não sabia”, diz Kaká Werá, "mas sem querer iniciava a delicada lição da arte de dizer adeus" (Jecupé, 2002, p. 30). Adeus à terra, adeus aos/às seus/suas mortos/as pela violência colonial, fuga permanente, desorientação cultural, enfim, situações próprias a esse êxodo corriqueiro que é caudatário de uma perspectiva colonizatória e, depois, modernizadora para a qual o progresso significa crescimento econômico sem limites, situação que, em uma economia periférica dependente de commodities, leva à usurpação e à concentração da terra, à crise ecológica e ao subemprego, à concentração de renda e à miséria social como seus eixos fundamentais. Tudo o que estiver no caminho será arrasado gradativamente. Todos os que representarem ideais de vida alternativos serão deslegitimados e até eliminados. Eis uma das grandes linhas de força da constituição, do desenvolvimento e da evolução de nossa sociedade. De todo modo, retomando nosso argumento, a expulsão territorial e a ameaça da morte permanente condenam os povos indígenas a um êxodo cruel e intensificado, que lhes consolida uma perspectiva grupal-pessoal de estrangeiros no próprio país, sem lar, sem voz e sem vez. E isso, como estamos argumentando, influencia de modo indelével e pungente a literatura produzida pelos/as escritores/as indígenas, conferindo-lhes crueza, tristeza e desilusão antropológicas. Mais uma vez é Kaká Werá Jecupé quem nos fala:

Ao chegarmos e habitarmos entre os guaranis, em São Paulo, a cidade acabou pedindo o nome do pai e dos guaranis em troca de sobrevivência. Disseram que sem nome e número civilizados não se existia. Então o que éramos? Éramos apenas, não existíamos. Ficamos muito tempo sem existir até faltar água e recursos da mata e precisarmos trocar com os civilizados meios para sobreviver. Uma das coisas trocadas foram os nomes (Jecupé, 2002, p. 26-27).

Note-se o duplo aspecto desse deslocamento forçado, da violência própria ao êxodo colonialmodernizante: o fato de que a autocompreensão normativa e a consciência de si ficam jogadas na lama, sendo a vida reduzida quando muito à sobrevivência física; e essa situação de der obrigado/a assumir uma identidade branca como condição até do mais básico assistencialismo, como se mesmo aqui, na questão da sobrevivência material (e não mais moral), a perda de identidade fosse o ponto fulcral para o atendimento institucional das necessidades (materiais) desses grupos indígenas. Assim é que Kaká pode afirmar que, nessa situação de êxodo, de desterritorialização e de fuga, a consciência de si e a autocompreensão normativa - que são a condição para uma vida estável e sadia - simplesmente não existem, são degradadas ao extremo e, em muitas situações, têm de ser abandonadas como questão da sobrevivência. É nesse sentido que a expulsão dos próprios territórios e a fuga forçada relativamente à violência reduzem os/as indígenas a meros objetos da sociedade envolvente. E, fora de seu contexto, sem nenhum contexto, em verdade, escorraçados de um lado para outro, vivendo de migalhas, dos restos lançados pela sociedade envolvente, esses/a mesmos/as indígenas transitam do luto para a esperança, da dor para a nostalgia, do passado para 
o presente, da violência para o sofrimento. $\mathrm{O}$ não lugar e o não reconhecimento, ligados a uma postura de perseguição e de desprezo permanentes, com efeito, como que destroem a vida desses povos indígenas, diminuindo profundamente suas possibilidades existenciais e abalando sua resistência contra a degradação e a morte.

Até agora fico dourando-me ao sol nesse rio da minha lembrança. Pelas aldeias do litoral, ouvia histórias de séculos, ouvia tristes cantigas guarani, rememorando descaminhos. Um labirinto de saudades que os caciques contavam. Da terra sem males. Presa em migalhas nas bocas guaranis, guardada na memória dos anciãos. Largados ao sol. Pintando o passado no silêncio (Jecupé, 2002, p. 36).

A terra sem males, a dignidade restabelecida. Note-se essa correlação estreita entre a posse do território simbólico-material com a alegria e a identidade reconquistadas, assim como pudemos perceber, acima, a interseç̧ão entre a perda dos territórios culturais, o êxodo permanente e a descaracterização normativa. Anseia-se por esse espaço simbólico-material de fartura, de paz e de enraizamento; deplora-se a condição de pária, de marginalizado/a, de estrangeiro/a em seu próprio país. Ora, é aqui que aparece a quinta característica fundamental da literatura indígena brasileira, em particular nos casos de Kaká Werá Jecupé e de Eliane Potiguara, que estamos estudando nesta seção. Trata-se da pertença, da profunda vinculação à condição e à causa indígenas e, assim, a construção e a dinamização de um eu-nós lírico-político que se ergue dessa situação de exclusão, de marginalização e de violência e reage em termos de um ativismo, de uma militância e de um engajamento na esfera pública, como sujeito políticocultural que assume protagonismo em relação à sua história, ao seu presente e ao seu futuro. É nesse sentido, aliás, que a literatura indígena vai da tradição à crítica do presente, a retomada e a reafirmação da tradição como crítica do presente, em que a valorização da singularidade étnico-antropológica e a reconstrução da história de violência vivida e sofrida pelos povos indígenas passam para primeiro plano da voz-práxis estético-literária, determinando-lhe seu caminho programático, seu conteúdo normativo e sua vinculação cultural.

Eu sou Kaká Werá Jecupé, um Txucarramãe que percorre o caminho do Sol, de acordo com a pintura do urucum escrita nesse corpo que guarda a história milenar de nosso povo, desde os Tubaguaçus primeiros, desde os Coroados primeiros, os primeiros Tupinambás - os adornados da plumagem do arco-íris em cintilantes cocares, os que desde sempre desenham e talham as douradas flechas dos raios de Tupã - pelos tempos, luas e luas (Jecupé, 2002, p. 15).

Por outras palavras: eu, Kaká, sou um povo, sou a história, o passado, o presente e o futuro de muitos povos indígenas. A literatura de autoria indígena, portanto, assume desde o início essa pertença como sua base, sua dinâmica e seu direcionamento. Valoriza e reafirma a tradição ancestral, utiliza suas histórias de humanidade como fundamento normativo tanto para sua autocompreensão quanto para sua postura de crítica social, de resistência cultural, de luta política e de práxis pedagógica, e, finalmente, a partir de todo esse arcabouço cultural, desvela as situações de marginalização, de exclusão e de violência enfrentadas pelos povos indígenas no contexto de nossa modernização conservadora. É uma literatura de cunho político, como vimos acima, marcada pelo comprometimento direto e pela publicização de sujeitos, histórias, práticas e valores alternativos àqueles hegemônicos em nossa sociedade; é o relato, a práxis do/a oprimido/a em busca de si, em reconstrução de si, de sua pertença, de seu Brasil. A literatura indígena brasileira, como de resto a literatura de minorias em geral, marca a superação da invisibilização, do silenciamento e do privatismo impostos a esses mesmos grupos minoritários e, nesse sentido, assume diretamente a condição e a causa dos próprios indígenas como sua bandeira de luta, como seu aguilhão crítico, como política cultural fundamental. É por isso que, na reafirmação dessa pertença, na valorização dessas raízes étnico-culturais e na denúncia da violência histórica, a literatura indígena une-se, como práxis política que é, ao próprio movimento indígena brasileiro, não podendo ser entendida a não ser dentro desse grande objetivo de politização dos povos indígenas, de sua vinculação pública, política e cultura. E, com isso, Eliane Potiguara, assim como Kaká Werá, pode comprometer-se de modo pungente com a luta em prol da causa indígena, exatamente por carregar, enquanto escritora indígena, toda a herança antropológica e todo o peso da violência história enquanto indígena: 
Nosso ancestral dizia: Temos vida longa! / Mas caio da vida e da morte / E range o armamento contra nós. / Mas enquanto eu tiver o coração aceso / Não morre a indígena em mim / E nem tampouco o compromisso que assumi / Perante os mortos / De caminhar com minha gente passo a passo / E firme, em direção ao sol. / Sou uma agulha que ferve no meio do palheiro / Carrego o peso da família espoliada / Desacreditada, humilhada / Sem forma, sem brilho, sem fama (Potiguara, 2018, p. 102-103). ${ }^{6}$

\section{Minorias como politização, literatura como ativismo}

A esfera estético-literária não é apenas um fenômeno diletante (embora não exista nenhum problema ou empecilho quanto a esta opção teórico-existencial), mas, sim, - e, conforme pensamos, de modo fundamental - uma arena de luta e de hegemonia político-cultural. Nós podemos perceber, seja na academia, seja no dia a dia da esfera pública, a utilização da arte como ferramenta política fundamental de sustento e/ou de desconstrução e de deslegitimação de sujeitos sociais, de conteúdos políticos, de práticas e de valores sociais - a última eleição presidencial, a propósito, foi muito sintomática desse sentido político e politizante da arte, da literatura. No caso da literatura de minorias de um modo geral e da literatura indígena brasileira em particular, essa politicidade aparece em cheio e estoura diretamente na esfera pública, pelas razões já comentadas acima: como construção político-normativa, as diferenças na esfera pública desvelam a politicidade que lhes constitui, os processos de violência simbólico-material que estão na base da construção e da reprodução de si mesmas e dos sujeitos e das relações que as envolvem; no mesmo sentido, a manifestação das e como diferenças não tem condições e nem se processa de outro modo que não como politização abrangente, inclusiva e radical, politização de si e do contexto circundante no qual elas são produzidas e legitimadas, contexto a partir do qual elas encontram seu sentido e sua dinâmica - não é possível esconder a própria diferença, a condição de e como minoria, e isso é o começo da política, em termos de contradição e de embate entre posições antagônicas. Dito isso, a conclusão a que chegamos é óbvia, mas sempre muito importante para o trabalho nas humanidades e nas letras: literatura significa empoderamento, assim como domínio da língua, conhecimento epistemológico e autoconsciência histórica também o significam e o promovem.

A literatura é um espaço de luta e, dentro dele, um instrumento de livre manifestação do que se é e de como se chegou a ser isso que se é. No caso dos povos indígenas, como mais uma vez vimos e desenvolvemos ao longo do texto, é por meio de uma voz-práxis estético-literária de cunho carnal, pungente e vinculado, profundamente político e politizante, que o eu-nós líricopolítico desenvolve e publiciza seja sua singularidade étnico-antropológica, utilizando-a como crítica do presente, seja, para o nosso caso aqui, o compartilhamento das suas histórias e experiências de violência e de negação como minoria político-cultural, como vítimas de nossa modernização. Assim, o relato da diáspora, do êxodo, da desterritorialização, com toda a odisseia ligada à perda de identidade, ao não reconhecimento e à ameaça constante da existência física molda seja o árduo trabalho de reafirmação e de consciência de si, em meio ao oceano de violência e de trevas que envolve os povos indígenas (e as próprias minorias), seja o caminho gradativo de volta para casa, ou seja, de retomada e de reconsideração de seus espaços físicos e culturais. E isso se deve, para finalizar, ao mais precioso ensinamento que as minorias de um modo geral e os povos indígenas em particular legam a todos/as nós que, além de professores/as, somos também cidadãos/ãs, professores/as porque cidadãos/ãs: de que não existe autonomia privada sem cidadania política, de que a participação e o enraizamento na esfera pública são e serão sempre o único lugar, o único caminho e o único instrumento para o enquadramento e a transformação da injustiça, o que exige presença permanente e intensa de todos/as os/as interessados/as, em particular dessas mesmas minorias.

\footnotetext{
${ }^{6}$ Ver também: Kopenawa e Albert (2015, p. 65-66).
} 


\section{Referências}

ALMEIDA, Maria Inês de; QUEIROZ, Sônia (2004). Na captura da voz: as edições da narrativa oral no Brasil. Belo Horizonte: Autêntica; Fale/UFMG.

BANIWA, Gersem (2006). O índio brasileiro: o que você precisa saber sobre os povos indígenas no Brasil de hoje. Brasília: Laced/Museu Nacional.

DALCASTAGNÈ, Regina (2012). Literatura brasileira contemporânea: um território contestado. Vinhedo: Horizonte.

ESBELL, Jaider (2013). Tardes de agosto, manhãs de setembro, noites de outubro. Boa Vista: Edição do Autor.

ESCALANTE, Emilio del Valle (2015). Teorizando las literaturas indígenas contemporáneas. Raleigh: A Contracorriente.

FERNANDES, Florestan. (2008). A integração do negro na sociedade de classes. São Paulo: Globo, 2008.

GUAJAJARA, Sonia (2018). Sonia Guajajara. Organização de Kaká Werá. Coordenação de Sérgio Cohn e de Idjahure Kadiwel. Rio de Janeiro: Azougue.

HABERMAS, Jürgen (2012). Teoria do agir comunicativo: racionalidade da ação e racionalização social. São Paulo: Martins Fontes. v. 1.

JECUPÉ, Kaká Werá (1998). A terra dos mil povos: história indígena contada por um índio. São Paulo: Peirópolis.

JECUPÉ, Kaká Werá (2002). Oré Awé Roiru'a Ma: todas as vezes que dissemos adeus. São Paulo: TRIOM.

JEKUPÉ, Olívio (2002). Xerekó Arandu: a morte de Kretã. São Paulo: Peirópolis.

JEKUPÉ, Olívio (2009). Literatura escrita pelos povos indígenas. São Paulo: Scortecci.

KOPENAWA, Davi; ALBERT, Bruce (2015). A queda do céu: palavras de um xamã yanomami. São Paulo: Companhia das Letras.

KRENAK, Ailton (2015). Encontros. Organização de Sérgio Cohn. Rio de Janeiro: Azougue.

KRENAK, Ailton (2017). Ailton Krenak. Organização de Kaká Werá. Coordenação de Sérgio Cohn e de Idjahure Kadiwel. Rio de Janeiro: Azougue.

MUNDURUKU, Daniel (2012). O caráter educativo do movimento indígena brasileiro (1970-1980). São Paulo: Paulinas.

MUNDURUKU, Daniel (2016). Memórias de índio: uma quase autobiografia. Porto Alegre: Edelbra.

POTIGUARA, Eliane (2018). Metade cara, metade máscara. Lorena: DM Projetos Especiais.

SÁ, Lúcia (2012). Literatura da floresta: textos amazônicos e cultura latino-americana. Rio de Janeiro: Eduerj.

SOUZA, Jessé de (2012). A construção social da subcidadania: para uma sociologia política da modernidade periférica. Belo Horizonte: Editora da UFMG.

TUKANO, Alvaro (2017). Alvaro Tukano. Organização de Kaká Werá. Coordenação de Sérgio Cohn e de Idjahure Kadiwel. Rio de Janeiro: Azougue. (Coleção Tembetá).

WERÁ, Kaká (2017). Kaká Werá. Organização de Kaká Werá. Coordenação de Sérgio Cohn e de Idjahure Kadiwel. Rio de Janeiro: Azougu.e (Coleção Tembetá). 